Role of agricultural engineering in environmental and sustainable development for the valley and delta areas: 1184- 1192

\title{
EFFECT OF FRAGMENTATION ON IRRIGATION, AREA LOSSES, AND YIELD OF SOME CROPS IN SOHAG GOVERNORATE
}

\section{El-Gindy ${ }^{1}$ A.M. \\ El-Katib2'S.I. \\ Eid $^{3}$ S. F. \\ ABSTRACT}

Fragmentation is a problem which has affective role on adoption of new agriculture technology Field experiments were conducted at Gihena, Sohag governorate in season 2008/2009 to study the effect of fragmentation on irrigation, area losses, some agriculture operation. This study has a major to improve the work establishment and crop management in fragmentation to increase the yield and quality. The total area at Gihena center Sohag governorate was 1062 faddan divided into 12 plots. The owners' fields were 1666 farmer, the average area for every farmer between less than 6 kerat and 72 kerat.

The data indicated that:

The percent of owners for every were, $24.79 \%$ have area less than 6 kerat, $31.57 \%$ have area less than 11 kerat, $25.45 \%$ have area less than 23 kerat, $9.12 \%$ have area less than 35 kerat, $3.84 \%$ have area less than 47 kerat, $2.40 \%$ have area less than 59 kerat, $0.60 \%$ have area less than 71 kerat and $2.22 \%$ have area more than 72 kerat.

The area losses decreased by increasing field area, area losses were 13, 12.50 and $12 \%$ for field area 24,48 and 72 kerat respectively.

The irrigation water decreased by increasing field size for yields wheat, faba bean and clover, the quantity of irrigation water for wheat was decreased by 1.44, 3.61 and $7.12 \%$ when the field size increased from 6 kerat to 24, 48, 72 kerat respectively.

The yields were affected by fields size, the yield of wheat per feddan increased by 6.82, 9.10 and $18.18 \%$ when the field size increased from 6 kerat to 24, 48, 72 kerat respectively. Also the yield of faba bean had the same trend, the seed yield increased by 10.91, 20.00 and $23.64 \%$ when the field size increased from 6 kerat to 24, 48, 72 kerat respectively. The weight of clover cuts per feddan increased by increasing the field size, (1 faddan $=4200 \mathrm{~m}^{2}=24$ kerat, 1 kerat $=175 \mathrm{~m}^{2}$ ).

Key word: fragmentation, irrigation, area losses wheat, faba bean.

1-Prof. Dr. of Agric. Eng. Faculty of Agric., Ain Shams Univ.Cairo. Egypt.

2- Senior Res., Agric. Eng., Res. Ins., Agric. Res. Center, MOA, Cairo, Egypt.

3-Res., Agric. Eng. Res. Ins., Agric. Res. Center, MOA, Cairo, Egypt

The $17^{\text {th }}$. Annual Conference of the Misr Society of Ag. Eng., 28 October, $2010-1184-$ 


\section{INTRODUCTION}

$\mathrm{E}$ gypt is mainly an agricultural country in which agricultural and irrigation technologies are important role in supporting national economy. Agricultural growth depends greatly on productivity improvement. Production resources can be increased through infrastructural development, appropriate technology, new farming methods and farm management improvement. Countries with traditional agricultural structures face small and fragmented plots, cultivation is carried on to non- geometric small- scale plots which limit application of farm machinery, mechanization development, and putting to practice new cultivation methods.

Early in (1970), Hanna and El- Awady estimated land saving by over $10 \%$ due to using developed surface irrigation by long furrows. Therefore, application of modern technology. Aimed at increasing yield and reducing production costs, has a direct relationship with land consolidation and optimum size of cultivation. Arsalanbod, M.R., (2000) concluded that, in irrigation wheat, one percent of increase in farm size causes a 0.4 percent decrease in cost, and one percent decrease in fragmentation causes a 0.44 percent decrease of costs. Also Haidari, G.R (1996) showed that land consolidation causes a 20 percent increase in yield. Soltani,G. R., (1978) said that with increasing population pressure and more efficient technology, they are coming under increasing strain. In the long run, they may be not adaptive at all. Therefore, for an economic crop production it is necessary to execute land consolidation programs that can provide appropriate living standards for farmers. According to some studies, the optimum farm size for economic crop production should be at least $12 \mathrm{ha}$. El- Berry et. al. (2006) indicated that the saved agricultural land through different treatments ranged from about 6 to $12 \%$ which were occupied by the channels and ridges.

Elaph (2006) studied the land fragmentation and mentioned that the fragmentation in south Egypt was greater than it in north Egypt the avarege of farm size 2.2 feddan in south Egypt but it was 4.4 feddan in north Egypt throuth year 2000/2001. Also the percent of size farm less than feddan was $47.2 \%$ from total area in the south Egypt but it was $30.70 \%$ from total area in the north Egypt. On the other hand the percent 
increased to $82 \%$ and $65.6 \%$ for size less than 3 feddan in the south and north Egypt respectively. It added the disadvantage for land fragmentation were losses in agriculture area, change in uses of agriculture land, difficult of use new technology in agriculture, increases in crops costs and losses in irrigation water. El - Qousy (2008) showed that the true problem for Egyptian agriculture now and in the future it is the land fragmentation; it was less than one feddan. This will causes weakly in water management and yield. We need to a way can be collected the small size farm.

\section{MATERIALS AND METHODS}

$\underline{\text { Small size area compared with total area: }}$

The total small size area at Jihena center Sohag governorate was 1062 feddan divided into 12 plots. The plots were:

1- El gazra plot

2- Abo raway plot

3- sglat abd el-hamid plot

4- sglat el- mashaygh plot

5- El-karb el- bahary plot

6- El-karb el-kably plot

7- El-kerat plot

8- Maswel el- gharby plot

9- Maswel el-sharky plot

10- Ghrsa kzaza plot

11- El-ghars el- bahary plot

12- El-ghars el-kably plot.

The area losses were measured and determined for each size of field. The water applied $\mathrm{m}^{3} / \mathrm{fed}$ was measured by flow gage on pump, for every irrigated for each size field. Wheat seeds (Giza 168) was planted in 27/11/2008 and received 6 irrigations. Faba bean seeds (Giza 674) was planted in 14/11/2008 and clover seeds (Giza 4) was planted in $25 / 10 / 2008$ the yields received the same agricultural practices as usual in the area. 


\section{RESULTS AND DISCUSSION}

1 - The percent of small size area compared with total:

Surfing data presented in table (1) and Fig. (1) indicate that, Jehina center area was 1062 feddan divided into 12 plots, (feddan $=4200 \mathrm{~m}^{2} \&$ kerat $=$ $175 \mathrm{~m}^{2} \& 1$ feddan $=24$ kerat), the total owner farmer were 1666 person. Also data indicated that $94.78 \%$ of farmers have less than 2 feddan this percentage divided into $24.79 \%$ have less than 6 kerat, $31.75 \%$ have more than 6 kerat and less than $12 \operatorname{kerat}(0.5$ feddan), this means that $56.54 \%$ of owner farmers have less than 0.50 feddan.

\section{Table (1): The percent of owners' fields and their area size compared with total area.}

\begin{tabular}{|c|c|c|c|c|c|c|c|c|c|}
\hline Alot Area & $\begin{array}{c}<6 \\
\text { Kerat }\end{array}$ & $\begin{array}{c}6-11 \\
\text { kerat }\end{array}$ & $\begin{array}{c}12-23 \\
\text { kerat }\end{array}$ & $\begin{array}{c}24-35 \\
\text { kerat }\end{array}$ & $\begin{array}{c}36-47 \\
\text { kerat }\end{array}$ & $\begin{array}{c}48-59 \\
\text { kerat }\end{array}$ & $\begin{array}{c}60-71 \\
\text { kerat }\end{array}$ & $\begin{array}{c}<72 \\
\text { kerat }\end{array}$ & total \\
\hline El gazra plot & 18 & 18 & 9 & 9 & 1 & 3 & 3 & 3 & 64 \\
\hline $\begin{array}{c}\text { Abo raway } \\
\text { plot }\end{array}$ & 76 & 70 & 52 & 9 & 5 & 1 & -- & 1 & 214 \\
\hline $\begin{array}{c}\text { Sglat abd el- } \\
\text { hamid plot }\end{array}$ & 17 & 64 & 60 & 27 & 10 & 3 & 1 & 2 & 184 \\
\hline $\begin{array}{c}\text { Sglat el- } \\
\text { mashaygh } \\
\text { plot }\end{array}$ & 31 & 55 & 49 & 19 & 7 & 4 & 2 & 2 & 169 \\
\hline $\begin{array}{c}\text { El-karb el- } \\
\text { bahary plot }\end{array}$ & 26 & 41 & 36 & 17 & 6 & 7 & 1 & -- & 134 \\
\hline $\begin{array}{c}\text { El-karb el- } \\
\text { kably plot }\end{array}$ & 32 & 41 & 45 & 10 & 3 & 1 & 1 & 3 & 136 \\
\hline El-kerat plot & 83 & 72 & 37 & 6 & 1 & 2 & -- & 1 & 202 \\
\hline $\begin{array}{c}\text { Maswel el- } \\
\text { gharby plot }\end{array}$ & 38 & 43 & 21 & 17 & 7 & -- & -- & 4 & 130 \\
\hline $\begin{array}{c}\text { Maswel el- } \\
\text { sharky plot }\end{array}$ & 4 & 24 & 26 & 6 & 6 & 2 & -- & 3 & 71 \\
\hline $\begin{array}{c}\text { Ghrsa kzaza } \\
\text { plot }\end{array}$ & 33 & 35 & 43 & 10 & 12 & 4 & 1 & -- & 138 \\
\hline $\begin{array}{c}\text { El-ghars el- } \\
\text { bahary plo }\end{array}$ & 21 & 35 & 29 & 15 & 5 & 5 & -- & 9 & 119 \\
\hline $\begin{array}{c}\text { El-ghars el- } \\
\text { kably plot }\end{array}$ & 34 & 28 & 17 & 7 & 1 & 8 & 1 & 9 & 105 \\
\hline $\begin{array}{c}\text { total } \\
\text { \% of owners } \\
\text { fields and } \\
\text { their area } \\
\text { size. }\end{array}$ & 413 & 526 & 424 & 152 & 64 & 40 & 10 & 37 & 1666 \\
\hline$*$ Total area & $1062 \mathrm{fed}$ & 31.57 & 25.45 & 9.12 & 3.84 & 2.40 & 0.60 & 2.22 & \\
\hline & & & & & & & & & \\
\hline
\end{tabular}

* Total area 1062 feddan $\quad$ Feddan $=24$ kerat $=4200 \mathrm{~m}^{2} \quad$ kerat $=175 \mathrm{~m}^{2}$ 
Also $25.45 \%$ have more than 11 kerat and less than 24 kerat ( 1 feddan), $9.12 \%$ have more than 23 kerat and less than 36 kerat and $3.84 \%$ have more than 35 kerat and less than 48 kerat (2feddan). On the other hand only $2.22 \%$ of owner farmers have more than 3 feddan in Jehina center Sohag Governorate and $3 \%$ have more than 47 kerat and less than 72 kerat (3 feddan).

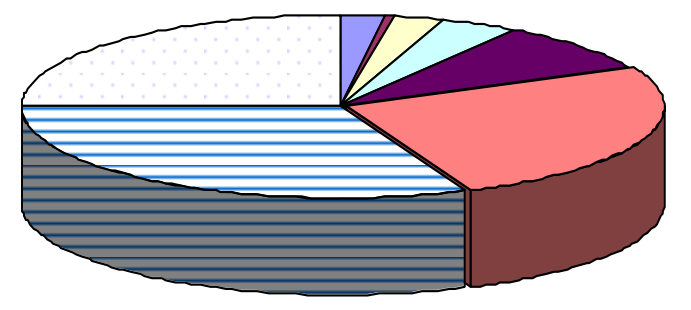

$\square$ More than 72 kerat

60-71 kerat

$\square$ 48-59 kerat

$\square$ 36-47 kerat

ㄴ 24- 35 kerat

ㄷ 12-23 kerat

$\square 6$ - 11 kerat

$\square$ Less than 6 Kerat

Fig (1): Percent of small size area compared with total area.

\section{2- Effect of fragmentation on area losses \%:}

Data presented in table (2) and Fig. (2) indicated that, the estimated area losses area less than 6 kerat $\left(1\right.$ kerat $\left.=175 \mathrm{~m}^{2}\right)$ losses area was $147 \mathrm{~m}^{2}$ (for 6 kerat) it is equal $14 \%$ from total area $\left(1050 \mathrm{~m}^{2}\right)$ also from data presented in table (2) it is clear that the area losses decreased by increasing field area, area losses were 13, 12.50 and $12 \%$ for field area 24, 48 and 72 kerat respectively. These losses area were in divided field into small basins to control on irrigation water and field ridges.

\section{3-Effect of fragmentation on irrigation quantity $\mathrm{m}^{3}$ /fed:}

The effect of fragmentation on irrigation water quantity $\mathrm{m}^{3} / \mathrm{fed}$ are presented in table (2) and Fig. (3) from the data it is clear that the irrigation water decreased by increasing field size for yield of wheat, faba bean and berseem, the quantity of irrigation water for wheat was decreased by $1.44,3.61$ and $7.12 \%$ when the field size increased from 6 kerat to $24,48,72$ kerat respectively. Also the quantity of irrigation water 
for one feddan faba bean decreased by $2.20,3.78$ and $6.49 \%$ when the field size increased from 6 kerat to 24, 48, 72 kerat respectively. Also the berseem had the same trend the irrigation water for one feddan decreased by 1.47, 2.99 and $9.52 \%$ when the field size increased from 6 kerat to $24,48,72$ kerat respectively. These increasing in water may be due to the small size field not leveled by laser or manual scraper and there was not a modified surface irrigation.

\section{4- Effect of fragmentation on yield of wheat, faba bean and Barseem:}

The effect of fragmentation on yields of wheat, faba bean and barseem are presented in table (2) and Fig. (4).It is clear that the yields were affected by field size, the yield of wheat per feddan increased by 6.82 , 9.10 and $18.18 \%$ when the field size increased from 6 kerat to 24, 48, 72 kerat respectively. Also the yield of faba bean had the same trend, the seed yield increased by 10.91, 20.00 and $23.64 \%$ when the field size increased from 6 kerat to 24, 48, 72 kerat respectively. Also from the data it is clear that the weight of barseem cuts per feddan increased by increasing the field size, the weight of barseem cuts increased by 0.28 , 1.41 and $3.66 \%$ when the field size increased from 6 kerat to 24, 48, 72 kerat respectively. These decreased in yield my be due to small area has a high percent of area losses and it is a adoption of using agricultural machinery.

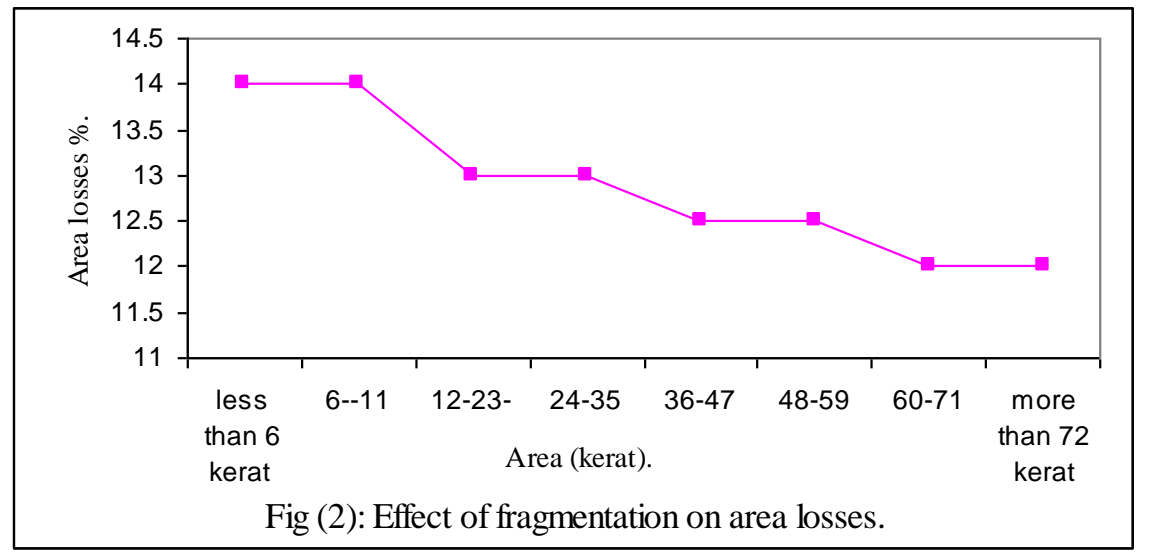

The $17^{\text {th }}$. Annual Conference of the Misr Society of Ag. Eng., 28 October, 2010 - 1189 - 

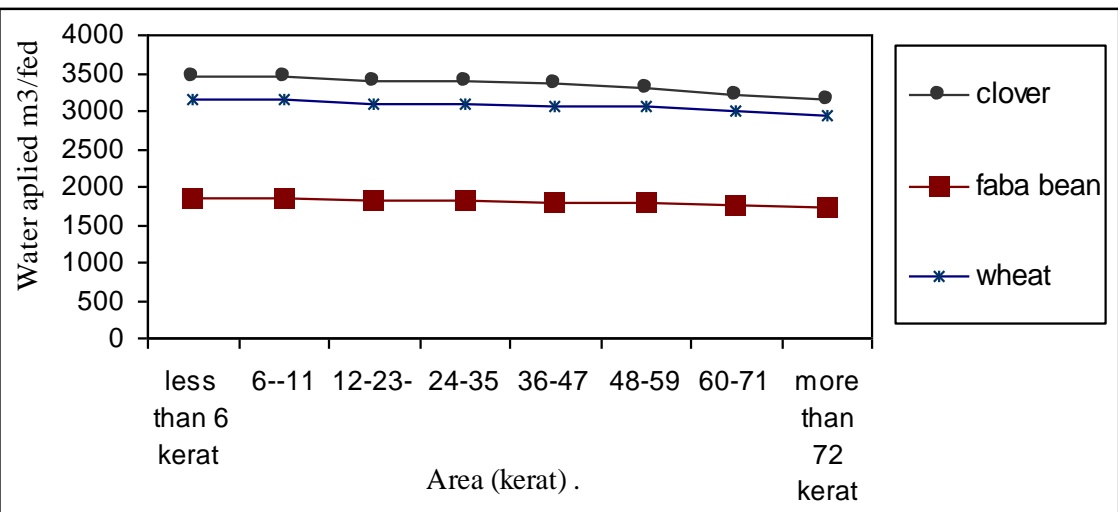

Fig (3) : Effect of fragmentation on water applied.

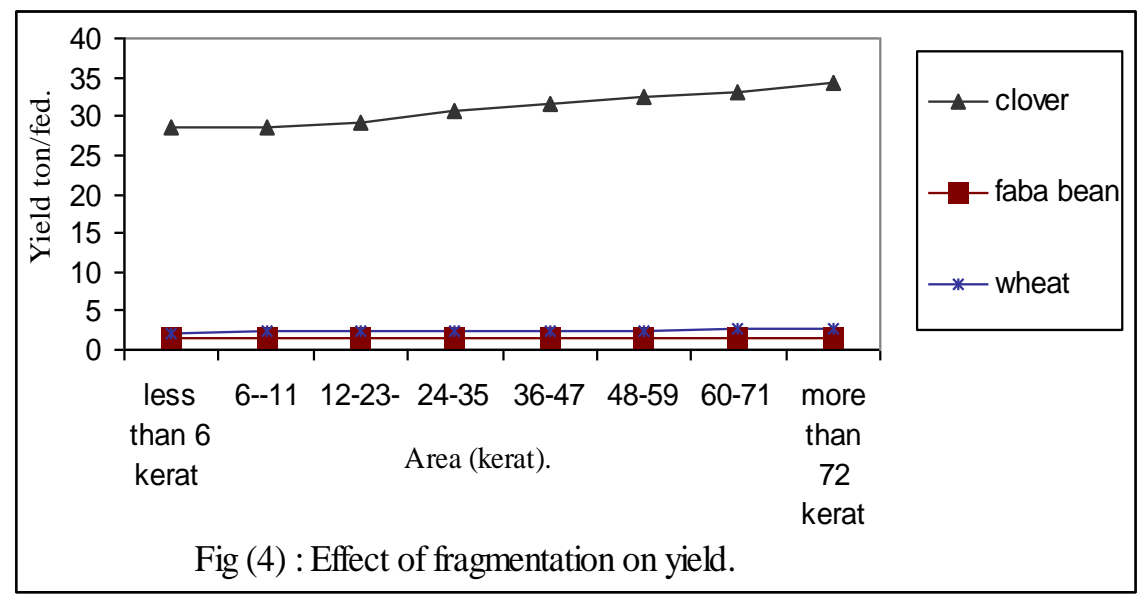

Table (2): Effect of fragmentation on area losses, irrigation and yield for barseem, faba bean and wheat.

\begin{tabular}{|c|c|c|c|c|c|c|c|}
\hline & $\begin{array}{c}\text { Area } \\
\text { losses, } \\
\%\end{array}$ & \multicolumn{2}{|c|}{$\begin{array}{c}\text { Irrigation quantity } \\
\mathrm{m}^{3} / \text { fed. }\end{array}$} & \multicolumn{3}{c|}{ Yield } \\
& & Barseem & $\begin{array}{c}\text { Faba } \\
\text { bean }\end{array}$ & wheat & Barseem & $\begin{array}{c}\text { Faba } \\
\text { bean }\end{array}$ & wheat \\
\hline < 6 Kerat & 14.00 & 3450 & 1850 & 3160 & 28.50 & 1.40 & 2.20 \\
\hline 6- 11 kerat & 14.00 & 3450 & 1850 & 3160 & 28.60 & 1.45 & 2.30 \\
\hline 12-23 kerat & 13.00 & 3400 & 1810 & 3100 & 29.30 & 1.46 & 2.35 \\
\hline 24- 35 kera & 13.00 & 3400 & 1810 & 3100 & 30.65 & 1.48 & 2.35 \\
\hline 36-47 kerat & 12.50 & 3350 & 1790 & 3070 & 31.55 & 1.50 & 2.40 \\
\hline 48-59 kerat & 12.50 & 3300 & 1780 & 3050 & 32.50 & 1.51 & 2.40 \\
\hline 60-71 kerat & 12.00 & 3200 & 1750 & 3000 & 33.10 & 1.52 & 2.60 \\
\hline$>72$ kerat & 12.00 & 3150 & 1730 & 2950 & 34.40 & 1.53 & 2.60 \\
\hline
\end{tabular}




\section{CONCLUSION}

The results obtained can be summarized as follow:

The percent of owners for every were, $24.79 \%$ have area less than 6 kerat, $31.57 \%$ have area less than 11 kerat, $25.45 \%$ have area less than 23 kerat, 9.12\% have area less than 35 kerat, $3.84 \%$ have area less than 47 kerat, $2.40 \%$ have area less than 59 kerat, $0.60 \%$ have area less than 71 kerat and $2.22 \%$ have area more than 72 kerat.

The area losses decreased by increasing field area, area losses were 13, 12.50 and $12 \%$ for field area 24, 48 and 72 kerat respectively.

We need to find a law to be collected the small size farm and not divided the area by the inheritance system between families.

\section{REFERENCES}

El- Berry, A. M., F. G. El -Ebaby, S. S. Hassan and S. M. Fattouh, 2006: Performance of Locally Developed Surface Irrigation in Sugarcane Production. Misr J. Ag. Eng., 23(1): 169-191.

El - Qousy, D. A., 2008: Integration Water Management in Egypt Tenth Work shop. Partner in Development Company p11.

Hanna, K. F. and M. N. El- awady, 1970: Analysis of irrigation with long furrows. Ain Shams Univ. Press, Res. Bul. 674, Fac. Agric.; 19p.

Haidari, G. R, 1996: Land Consolidation and Agric. Dev. Iran. Agric. Econ. Dev. Q.J., 4 (1).

Arsalanbod, M.R., 2000: Effect of Farm Smallness and Fragmentation of Productive Units on Production Costs: Case of Irrigated Wheat in West Azerbaijan. Agric. Econ Dev. Quarterly J., 8 (2).

Soltani,G. R., 1978: Small Farm versus Large Farm Development in Iran. Indian J. Agric. Econ., 33: 94-102.

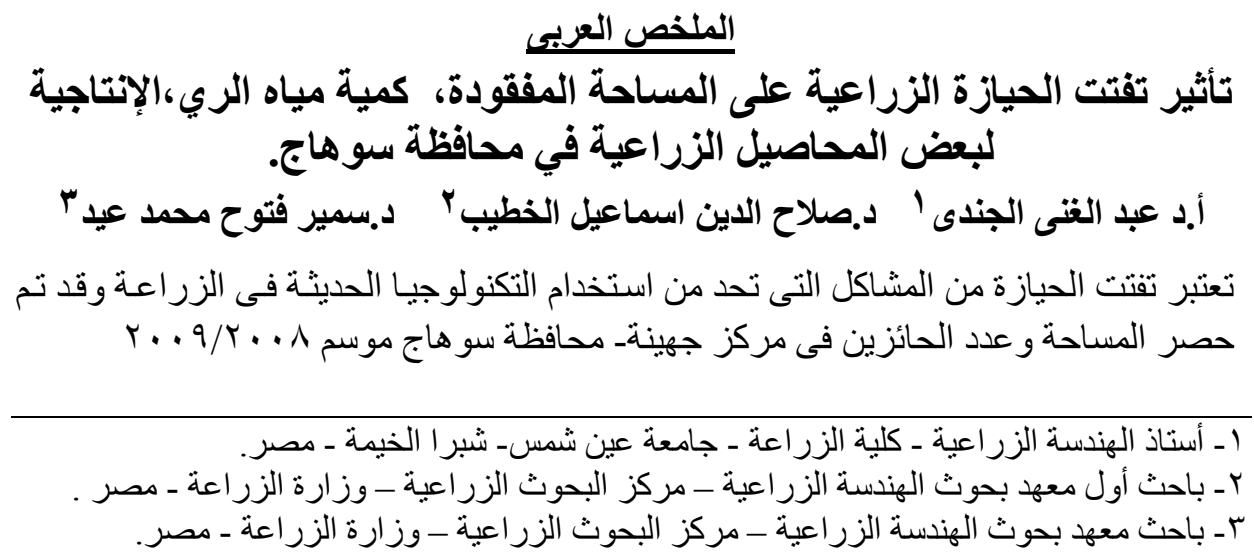


وذللك لدر اسة تأثير تفتت الحيازة وصغر المساحات على إجر اء العمليات الزر اعية وكمية المياه

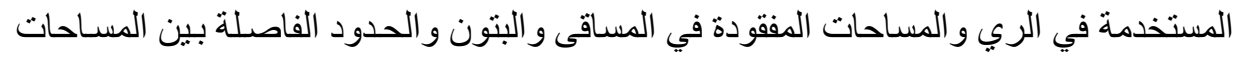

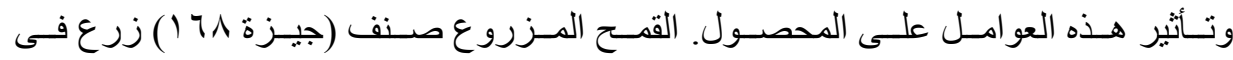

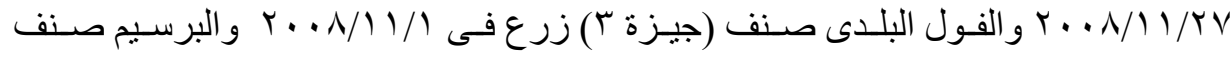

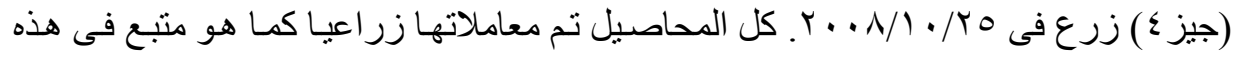
المنطقة.

\section{وأوضحث النتائج التالّى:-}

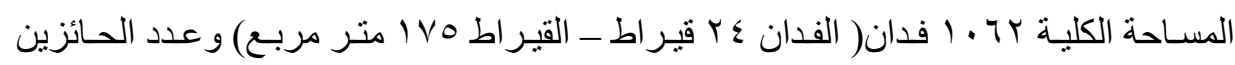

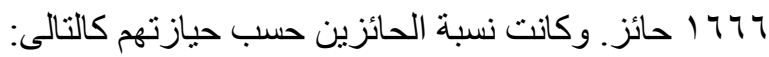

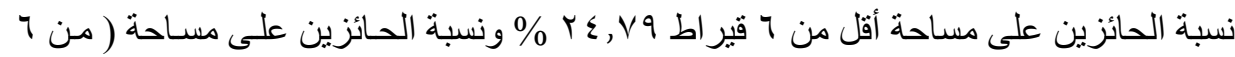

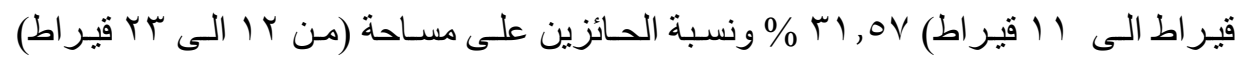

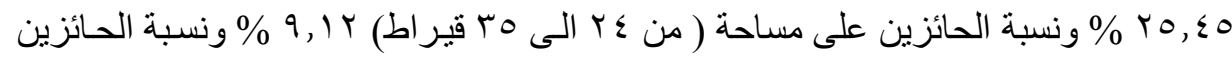

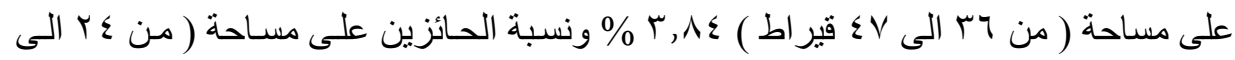

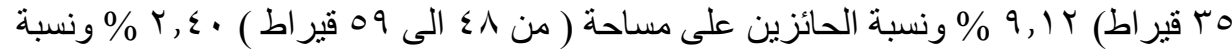

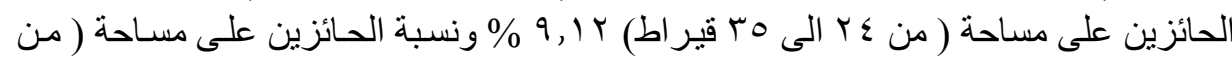

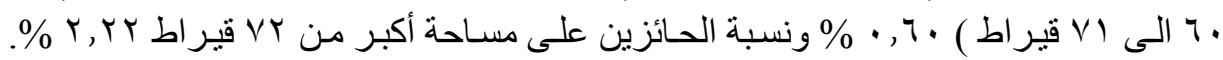

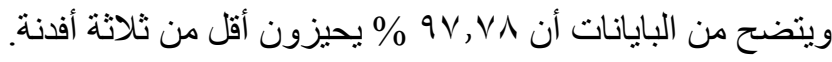

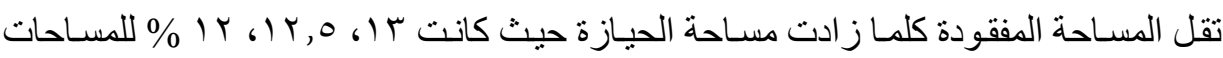

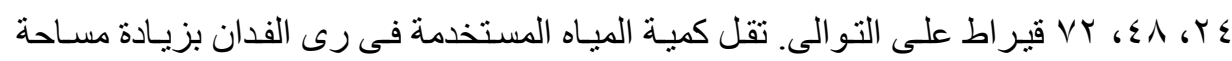
الحيازة لكل من محاصبل القمح و الفول البلدى و البرسيح.

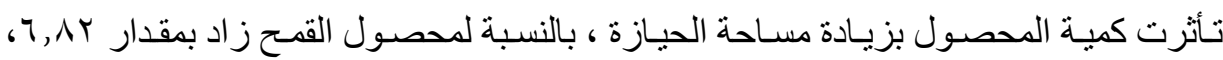

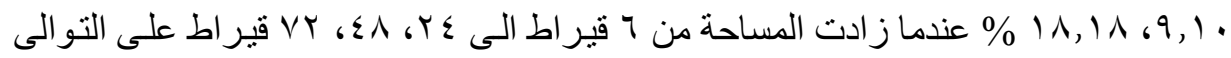

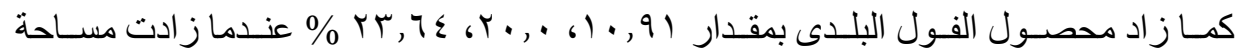

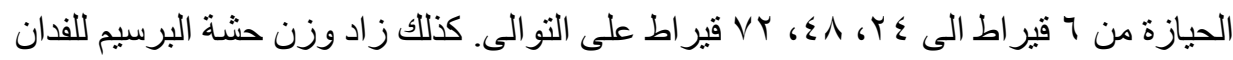

بزيادة مساحة الحيازة.

التوصيات:

نحن بحاجـة لعمل تشـريع (قوانين) لتشجيع المززارعين ذو الحيـاز ات الزر اعيـة الصـغيرة علي تجميع حياز اتهم بدلا من تفتيتها و الناتجة عن لتهن التوريث. 